\title{
Muslim Students' Understanding of The Interconnection of Gravity in Science and The Qur'an
}

\author{
${ }^{*}$ K Amalia1, Suliyanah ${ }^{1}$ \\ ${ }^{1}$ Department of Physics, Faculty of Mathematics and Natural Science, Universitas Negeri Surabaya, Surabaya 60231, \\ Indonesia
}

\begin{tabular}{l} 
Article Info \\
\hline Article history: \\
Received November 30, 2020 \\
Revised December 7, 2020 \\
Accepted December 10, 2020 \\
Available Online December 11, 2020 \\
\hline
\end{tabular}

Keywords:

Gravity

Science

The Qur'an

\begin{abstract}
Gravity is known as a discovery made by Sir Isaac Newton. Long before this theory was put forward, the Qur'an came down first, and some verses indicated the existence of gravity, but not everyone understood these signs. There are still many Islamic schools in Indonesia that have not yet studied science by relating the Qur'an. This study aims to determine the extent of Muslim students' understanding and to find out what Muslim students think about gravitational interconnection in science and the Qur'an. This research used descriptive qualitative research methods. The research data were obtained from interviews and questionnaires. Participants in this study were fifty participants, namely students from the Al-Amin Islamic Boarding School, Mojokerto, East Java. The results of this study indicate that the majority of students have a good understanding of Newton's gravitational interconnection in Science and the Qur'an. Most of the respondents argue that Newton's idea of gravity is related to the verses of the Qur'an, especially QS Al-Hajj 22:65, QS Al-Mursalat 77:25, QS Maryam 16:25, and QS Al-Qori'ah verses 1-5. This research can make Muslim students improve their understanding of gravity in science and the Qur'an and also increase their piety to God.
\end{abstract}

\section{INTRODUCTION}

Every occasion and its contents in the universe are a reality that is very impressive to the mind and heart of man. It is no wonder that since ancient times many scientists have used their minds to investigate the secrets and laws of nature that he can achieve to meet his needs and goals, one of which is Sir Isaac Newton. A western scientist was widely known to students and the public for his fundamental discoveries. At a time when western scientists are investigating why objects in space can spin around the sun in their respective orbits, Newton is present with his work Principia Mathematica Naturalis Causae which contains about universal gravitation, that every object in the universe interacts with other objects due to gravity (Young \& Freedman, 2002). Gravity has made the sun to be center of the solar system, made humans stand on the ground, made river water flow into the sea, and rainwater fell to the earth. Newton's research began during a quarantine due to the London plague epidemic by noticing an apple falling from a tree. Newton reasoned that the same interaction could cause an apple to fall from a tree and hold the planet in its orbit around the sun (Shamey, 2015).

Newton's idea of gravity is contained in a law, namely Newton's law of the gravity, it states "Every particle of matter in the universe attracts every other particle with a force that is directly 
proportional to the product of the mass of the particles and inversely proportional to the square of the distance between these particles" (Acedo, 2017). Newton's law of gravity can be written as a simple vector equation that lets $m_{1}$ and $m_{2}$ as two masses point separated by a distance $r_{12}$, that is the magnitude of the vector $\boldsymbol{r}_{\mathbf{1 2}}$ which leads from the masses $m_{1}$ to $m_{2}$. The force $F_{12}$ is given by the masses $m_{1}$ to $m_{2}$ is

$$
F_{12}=-G \frac{m_{1} m_{2}}{r_{12}^{2}} \hat{r}_{12}
$$

With $\hat{r}_{12}=\boldsymbol{r}_{\mathbf{1 2}} / r_{12}$, is the unit vector leading from $m_{1}$ to $m_{2}$ and $G$ is a universal constant of gravity whose value

$$
G=6,67 \times 10^{-11} \mathrm{~N} \cdot \mathrm{m}^{2} / \mathrm{kg}^{2}
$$

From Newton's third law, the force $F_{21}$ done by $m_{2}$ and $m_{1}$ is the negative of $F_{12}$. Which means $F_{21}$ is equal to $F_{12}$ but in the opposite direction. The amount of gravitational force exerted by $m_{1}$ particle mass on $m_{2}$ particles and the distance of $r$ is given by

$$
F=G \frac{m_{1} m_{2}}{r^{2}}
$$

A simple analogy might help, suppose a stone is thrown into the air. As long as a rock rises, the earth's gravity will slow down the rock's rise and finally stop the rock from moving so that the rock falls to the earth. On the other hand, if a rock is thrown at a speed faster than The Earth's Escape Velocity, the rock will go up forever. The nature of the rock movement depends on the strength of gravity and the upward impulse given to the stone. The same thing applies to the expansion of the universe (Hendi et al., 2017).

Based on Foster (2011:73), The origin of Newton's law of universal gravitation stems from empirical observations that have been made by previous scientists. Copernicus provided the basis for a pattern of thinking about the movement of the planets, which at first thought that the planets were moving around the earth, as in the Ptolemaic concept. Copernicus positioned the sun as the center of the planet's motion, in its circular motion, then from the observations of Tycho Brahe, Kepler proposed three empirical laws known as Kepler's laws of planetary motion:

1. All the planets are ellipses with the sun at one of its focal points.

2. The line connecting the planet to the sun will sweep across an equal area at the same time.

3. The square of a planet's period around the sun is proportional to the cube of the planet's average distance to the sun.

Kepler's laws are empiric, Kepler is unable to explain what underlies these laws. In the 17th century AD, Newton was present and was able to explain what underlies Kepler's laws and also showed that the same law is universally applicable to all objects with mass (Erwin, 2017).

The gravity on the sun makes the celestial bodies around the sun move around the sun according to their respective orbits, and gravity on the earth makes the earth have life, and keeps the moon around the earth, becomes a satellite, and moves around the earth. In the Qur'an, verses related to gravity are, for example, Q.S Maryam 19:25: "And, shake the base of the date palm towards you, the tree will drop ripe dates on you." The verse says that by shaking the tree, the fruit will fall. Such a concept is actually sufficient to illustrate that gravity has been conveyed by Allah SWT through the Qur'an, even though it is a common thing (Qurashi, 1989). Newton's Law of gravity states that each mass attracts another mass with a linear force. The magnitude of the gravitational force is proportional to the product of the mass of the two objects and is inversely proportional to the square of the distance between the two masses. Simply put, with a constant 
value, the greater the mass of the two objects, the greater the force produced, and the closer the distance between them, the greater the force produced. Multiplied by the acceleration due to gravity, this force produces weight. In the case of the earth, having an acceleration of $9.8-10$ $\mathrm{m} / \mathrm{s}^{2}$ makes the weight of the object on earth different when the object is on the moon or other planet, so it is the same in the universe. In the Qur'an, Allah SWT hints at the gravity on the earth, because the word of Allah SWT was indeed sent down to the apostles on earth to be conveyed to his people (Othman, 2015).

After seeing the concept, Qur'an and Science discussing gravity are essentially the same. Only Qur'an identifies globally and requires interpretation to understand it. All events in this universe are actually contained in the Qur'an, many philosophers of science are motivated by their religious beliefs to investigate nature. One of the most famous cases of western scientists, Isaac Newton in his religious outlook, Newton was driven by his belief in the supernatural to try to distinguish the order of the universe. After discovering this order, Newton did not stop believing in supernatural things like gravity but, felt that he had helped to describe the divine order in the movements of planets and stars (Purwanto, 2015).

According to Yusoff and Daneshgar (2011), The Middle East and Asia gave birth to many great thinkers in various fields, one of which is Al-Ghazali, who is a philosophy and religious scientist who states that the Qur'an is the source of inner knowledge (ma'rifa) and the source of knowledge. Al-Meresi with an extremist point of view agreed with Al-Ghazali's opinion and added that "all knowledge from the first to the last is in the Qur'an". The Qur'an and hadith are the main guidelines that influence the achievements and scientific research of Muslims (Cragun, 2015). The Qur'an and science are related to each other, although in fact, some people consider the Qur'an and science to be different things, the Qur'an is still considered as a guidebook in living life only. There are still many Islamic schools in Indonesia that have not conducted science learning by relating the Qur'an. The Qur'an is still used only as learning support for religious nature just like Aqedah, Figh, and so forth. Most of the Islamic schools or Islamic boarding schools only teach the interpretation of the Qur'an on life's problems, without connecting with science. The issue of science and the Qur'an is an exciting and contentious discussion among thinkers of religious and Islamic studies.

Furthermore, this study has two research questions: (1) How do junior high school Al-Amin Islamic Boarding School Students understand gravity in Science and Al-Qur'an? (2) What are the opinions of Muslim students in Al-Amin Islamic Boarding School about the interconnection of gravity in Science and the Qur'an?

\section{RESEARCH METHOD}

The method used in this research is the descriptive qualitative research method. The research data were obtained from qualitative research comes from primary data in the form of interviews and questionnaires. Participants in this study were fifty participants from the MA Al-Amin Islamic Boarding School, the majority of whom were boarding school students. The five sources in this study were referred to by the pseudonym of popular Indonesian nicknames, i.e., Suci (Sc), Ajeng (Aj), Yogi (Yg), Karisma (Kr), and Siska (Sk). There are several stages of data processing in this research includes the following steps: 


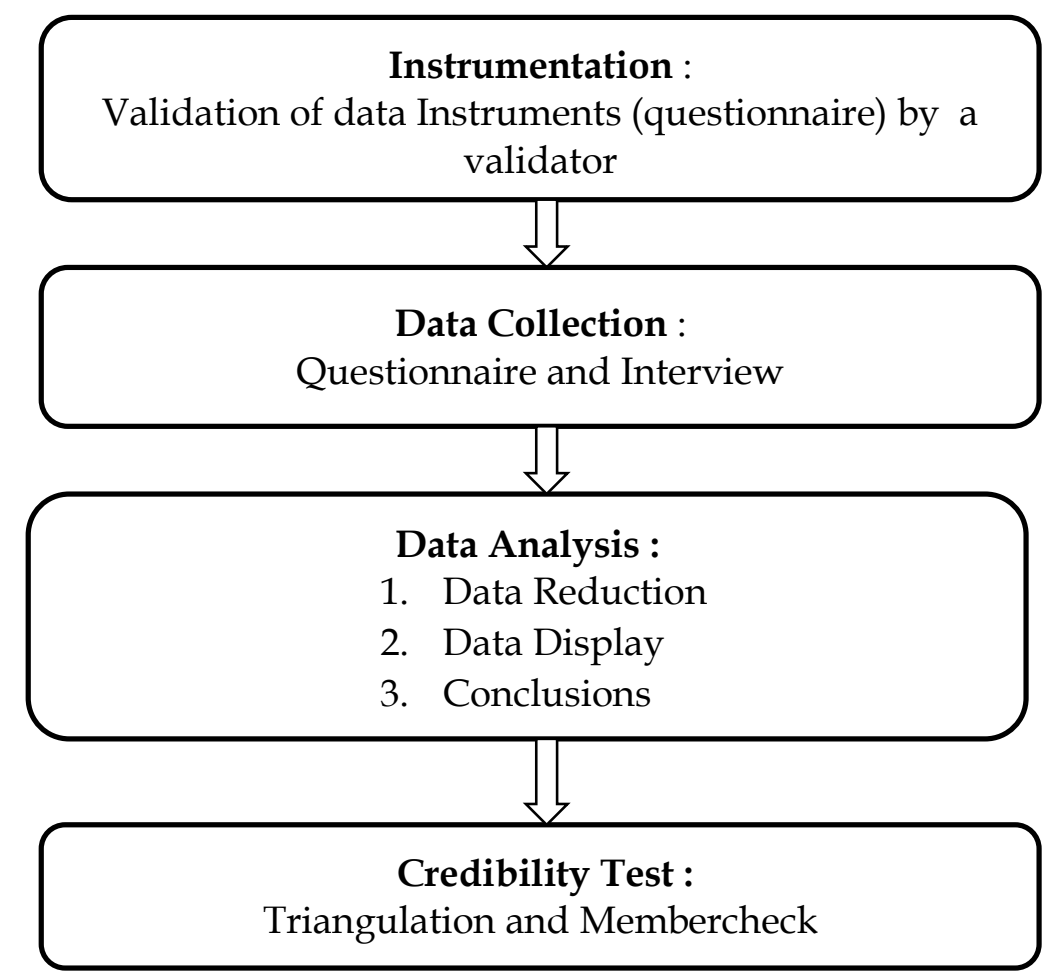

Figure 1. Data Processing Flowchart

Qualitative data from the results of semi-structured interviews were transcribed and analyzed by reading the answers to each interview question and the answers to the questionnaire (Creswell \& Clark, 2011).

\section{RESULTS AND DISCUSSION}

This section presents the results of the analysis and discussion of research conducted on Muslim students of the MA Al-Amin Islamic Boarding School. The results obtained include four factors, i.e., the existence of gravity in the universe, knowledge of gravity from a scientific perspective, knowledge of signs of gravity in the Qur'an, and understanding of the interconnection of gravity in science and the Qur'an.

\section{a. The Existence of Gravity in The Universe}

The following are some of the opinions of respondents regarding the existence of gravity in the universe:

"I believe that gravity exists in the universe, it may be difficult for us (humans) to believe in something that cannot be seen by the eye, but in fact, we live with its effects". [Sc]

" Gravity really exists, its existence cannot be separated from the will of Allah SWT. It's just that humans have limitations in seeing its form. Everything that happens in the universe by the will of Allah SWT as a sign of his greatness, humans are endowed with complete senses, but humans have limitations in their vision which only reach the limits of our own view". [Yg]

"I believe gravity exists because gravity is a phenomenon that Newtonian scientists proved by observing apples falling from trees. Newton thought the apple couldn't fail. There must be something that causes the apple to fall not upwards ". [Aj]

Based on respondents' statements, most respondents believe in the existence of gravity in the universe. According to Nurrohman (2019: 18), gravity is one of the natural phenomena that cannot be seen by the eye, cannot be touched, but can be felt the effects of its existence. When 
discussing the problem of something real and unseen, the first thing that arises is the boundaries between mystery and reality. Especially in science, even though what is discussed is real and empirical things, in fact, it still leaves a mystery even though it can be explained scientifically like gravity.

\section{b. Knowledge of gravity from a scientific perspective}

Based on the knowledge that has been obtained from the school, most of the respondents' opinions refer to Newton's findings, here are some opinions from respondents regarding gravity from a scientific perspective:

"Based on the knowledge that I have obtained from the school, gravity is the result of Newton's discovery which is contained in his law, namely Newton's law of universal gravity. The law of universal gravity states that the magnitude of the force of gravity is proportional to the mass of the object and inversely proportional to the square of its distance. The gravity of Newton's findings is universal, meaning that it does not only apply to the earth but also works on space objects ". [Yg]

"Gravity is a force, an attractive force between objects that have mass. All objects on earth that have mass will experience a gravitational force which always goes to the center of the earth, therefore objects that fall from a height will go downwards not upwards". [Sk]

"Gravity is one of Newton's discoveries which is defined as the force of attraction between two objects with mass. Earth's gravity causes objects that fall from a height to always go downward. The sun's gravity causes the planets to keep circulating the sun in their respective orbits. The sun has a relatively larger mass than other celestial bodies, based on Newton's universal law of gravity, it says that the magnitude of gravity is proportional to the mass of these objects, so the greater the mass of the object, the greater the gravitational force that works ". [Kr]

Based on the answers from the respondents, the knowledge of gravity from the scientific point of view of the respondents mostly refers to Newton's ideas. This is because at school the respondents still got knowledge about Newton's universal gravity only. Respondents' knowledge about gravity from a scientific point of view that has been obtained from schools can be categorized as quite good, respondents can define the term gravity, the discovery of gravity by Issac Newton, and the impact of gravity on the universe. According to Young and Freedman (2002: 355), Gravity is known as the attractive force between objects that have mass. The idea of gravity was first put forward by Sir Isaac Newton in the 17th century AD in his book "Principia Mathematica Naturalis Causae" which contains universal gravity, that every mass of particles in the universe interacts with other mass particles because of the force of gravity. In connection with the movement of planets in the solar system, Newton's gravity succeeded in explaining how the mechanism of two objects with mass interacting in gravitational attraction. According to Newton, the sun in the solar system has a very large tensile force so that it can attract space objects with relatively small mass such as planets, comets, asteroids to float on their respective orbits (Khoiri, 2018). 


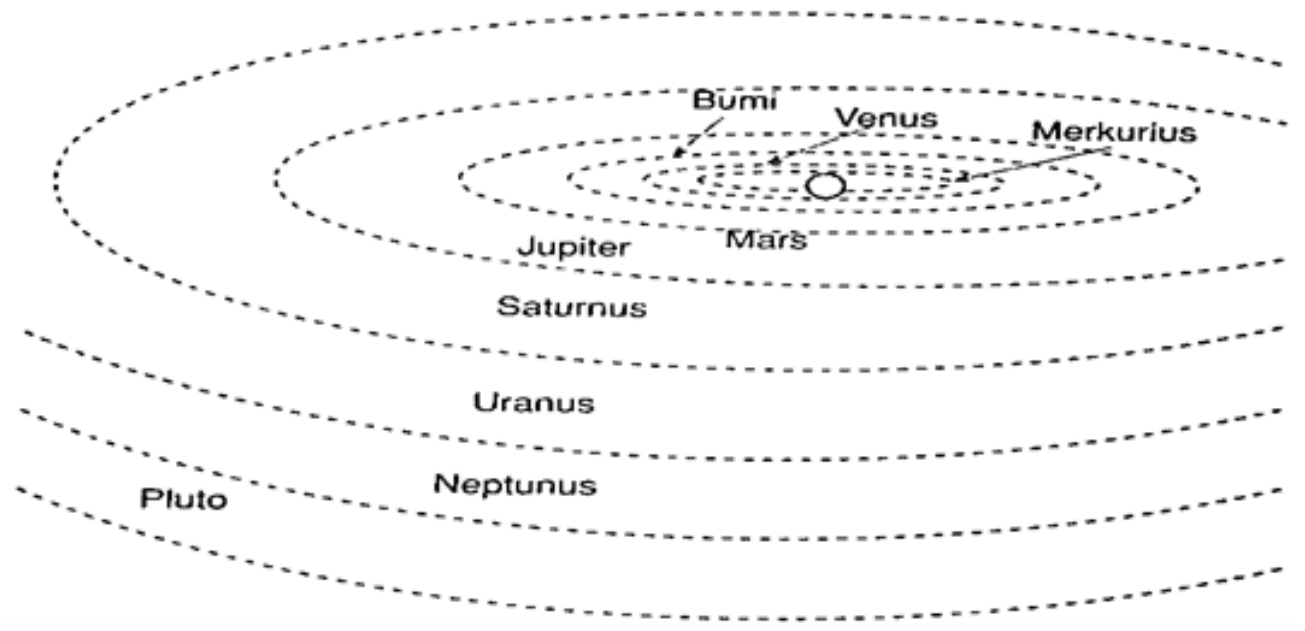

Figure 2. The planets circulating in their respective orbits

Newton's success in discovering gravity can explain how gravity works in normal situations or conditions, then the law of gravity is known as Newton's law of universal gravity. In ancient times Newton's laws of gravity were combined with Kepler's laws to locate objects in the sky and calculate their masses.

According to Hamzah (2016: 100), Newton's simplicity of calculations ( $\left.F=G \frac{m_{1} m_{2}}{r^{2}}\right)$ makes it easy for ordinary people to accept the law of gravity. Gravity exists in every mass particle in the universe. The mass of an object determines the amount of gravitational force that the object has. The greater the mass of the object, the greater the gravity of the object. Gravity also depends on distance. If an object moves further away, its gravity will weaken. Earth, sun, moon, planets, have a gravitational force, even small objects such as balls, rocks, sand, and dust, also have gravity. The content in the earth is also the cause of the difference in the magnitude of gravity in each region such as the type of soil, rock, mineral deposits, water and, so on.

\section{c. Knowledge about the existence of gravitational signs in the Qur'an}

In this section, each respondent has a different opinion about the signs of gravity in the Qur'an. Based on the interpretation of the book of interpretations and the translation of the al-Qur'an, the following are the opinions of the respondents regarding the signs of gravity in the Qur'an:

Most of the respondents showed the verses of the Qur'an about the power of Allah SWT to work the gravity in the universe,

"One of the verses that contain signs of gravity is the Q.S. Al-Hajj /22: 65:

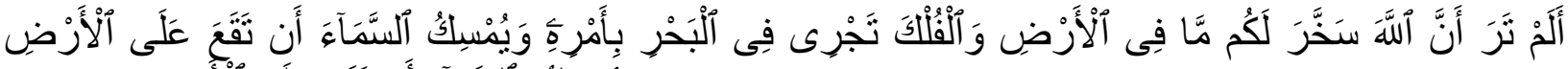

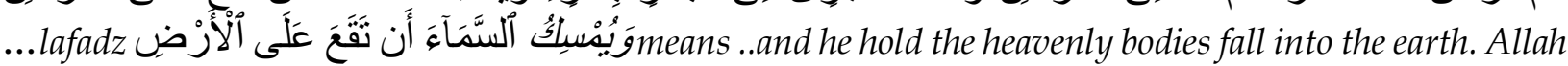
SWT has held heavenly bodies from falling to earth with force through the gravity". [Aj]

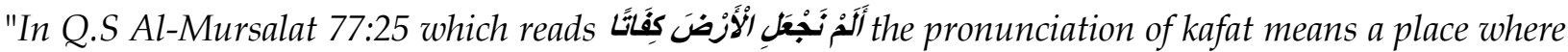
all objects gather, while the usual kifaatan is defined as objects that gather or an attraction to objects to gather where the attraction is gravity". [Sc]

"One of the verses that indicate gravity is QS Maryam verse 25. Which is the meaning of the verse" and shake the base of the date palm towards you the tree will drop ripe dates on you ", in the verse mentions the events of dates falling from a tree, this is by following Newton's theory of gravity, every object with mass experiences a gravitational force, the date is attracted by the earth's gravity which is downward or towards the center of the earth". [Kr] 
..and there is respondent show verses from the Qur'an about the impact of the loss of gravity on the universe,

"One of the verses that indicate gravity is Q.S Al-Qori' ah verses 1-5 which explains more about the result of the loss of gravity, people will be scattered like anai-anai, mountains like feathers scattered about". [Sk]

Masyaallah, the respondents' knowledge of gravitational signs in the Qur'an can be categorized as good, with the understanding of the interpretation obtained from the Islamic boarding school and guided by the tafsir book, being able to mention and explain the meaning of verses that contain gravitational signals. According to Mufid (2014: 146), long before Newton put forward his idea of gravity, Allah SWT had sent down the Qur'an in which there were various kinds of the phenomenon in the universe, especially gravity. In the verses mentioned about the gravity signal is a form of a gift from Allah SWT to his creatures and as a sign of his greatness, especially to humans who understand this and want to be grateful to him.

\section{d. Muslim Students' Understanding about the Interconnection of Gravity in Science and the Qur'an}

In this section, most respondents stated that gravity in science and the Koran is not contradictory, respondents conveyed signs of work-related gravity due to gravity in the universe and the impact of the loss of gravity.

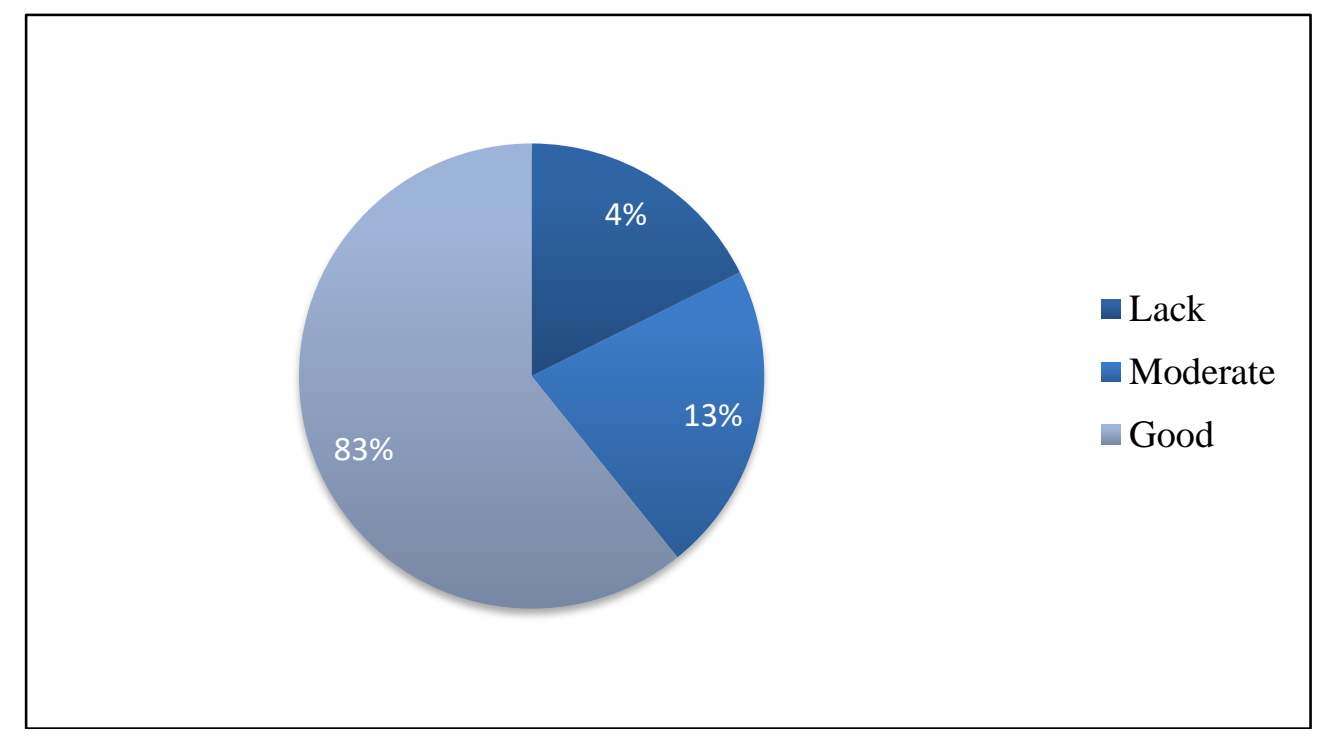

Figure 3. Respondent Understanding about the Interconnection of Gravity in Science and the Qur'an

Based on the diagram of the research results and the respondents' statement, Muslim students' understanding of the gravitational interconnection in science and the Qur'an can be categorized as good. Most of the respondents were able to relate Newton's findings with signs of gravity in the verses of the Qur'an. They have never received physics material that is related to the verses of the Qur' an before, but they have the ability to understand and interpret the verses of the Qur'an that they get from the Islamic boarding school. If learning activities in schools are carried out by integrating general subject matter with the Qur'an, it will be able to increase their understanding of physics concepts from a scientific perspective with verses in the Qur'an. According to the behavioristic learning theory by Edwin Guthrie, learning is an associative relationship between certain stimuli and certain responses (Suryabrata, 2004). Therefore, it is necessary to provide frequent stimuli so that the relationship becomes more lasting. The following are statements from respondents regarding the gravitational interconnection in science and the Qur'an: 
"Between science and the Koran are interconnected. Before scientists researched the existence of gravity, even Allah SWT has stipulated in the Koran, Earth's gravity causes all objects on earth to stand because the direction of Earth's gravity is towards the center of the Earth, Allah SWT said in QS Al-Mursalat 77:25 that Allah SWT making the earth a gathering place by presenting the earth's gravity whose direction is always towards the center of the earth, so that humans, animals, plants can live and stand on the earth safely". [Sc]

"Newton's law of universal gravitation describes gravity as an attractive force between mass and mass, for example, the earth and the moon. All objects in the universe attract each other because of the gravitational force on them. With the force of gravity, all celestial bodies run in balance. This is inseparable from the thoroughness of Allah SWT, which Allah SWT has hinted to humans about it in Q.S Al-Hajj 22:65. In the verse, it explains his power in holding heavenly objects from falling on the earth by working on gravity as long as Allah SWT still wants until the end ". [Yg]

"Gravity is the force of attraction between the mass of the particles in the universe." No science that contradicts the Qur'an because the Qur'an is a book of guidance for mankind that provides enlightenment regarding all phenomenon in the universe that has not happened or has happened". [Aj]

"Newton discovered gravity because he was inspired by apples falling from the tree, apples always fall because of the force that pulls the apples downward, this force is the earth's gravitational force. Before Newton discovered gravity through these observations in fact in the Koran it was already hinted at through QS Maryam verse 25. Which is the meaning of the verse "and shake the base of the date palm towards you the tree will undoubtedly drop ripe dates to you" verse it explains that by shaking the tree, the fruit will fall. This is actually sufficient to illustrate that gravity has also been conveyed by the al-Qur'an, and there is no contradiction between Newton's findings and the al-Qur' an ". [Kr]

"Gravity is the force of attraction between objects that have mass. Earth's gravity makes all objects on earth not float; humans can easily walk on earth. If gravity is lost, what will happen as in Q.S Al-Qori'ah verses 1-5, people will scatter like anai-anai, the mountains are like scattered feathers". [Sk]

According to al-Ghazali, al-Qur'an is the source of inner knowledge (ma'rifa) and the source of knowledge. Al-Meresi with an extremist perspective agreed with Al-Ghazali's opinion and added that "all knowledge from the first to the last is in the Qur'an". In a modern era like this, research on science and religion, including the theme of gravity, has been done a lot like Rusydin in his 2008 thesis which examines the force of gravity in the perspective of the Koran states that in the Koran the concept of gravity is only explained in general terms. it contains the origin of creation, the function of gravity creation, the process of loss of gravity, and the consequences of the loss of gravity (Rusydin, 2008). Sunardi et al. (2019), in his article "Earth's gravity signal (A tahlili study of QS. Al-Baqarah 2:74) Signs of earth's gravity at QS. al-Baqarah / 2: 74 are shown

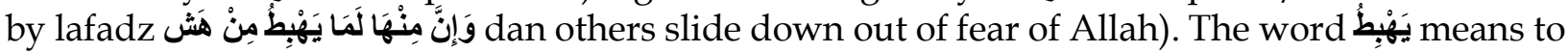
decline or go down. The word in this verse indicates an object that fell from the top to the surface, which is a stone. Stones that fall from a height to the bottom indicate that there are natural laws that Allah has imposed on stones and everything on earth. These laws are known as the force of gravity (Sunardi et al., 2019).

\section{CONCLUSION}

This study shows that most of the Muslim MA Al-Amin Islamic Boarding School students have a good understanding of the interconnection of gravity in science and the Qur'an. Most of the respondents argued that gravity in science was related to the verses of the Qur'an, especially QS Al-Hajj 22:65, QS Al-Mursalat 77:25, QS Maryam 16:25, and QS Al-Qori'ah verses 1-5. This research can make Muslim students improve their understanding of gravity in science and the Qur'an and also increase their piety to God. This study is still only Newton Classical gravity, for further research is expected to expand up to Quantum Gravity. 


\section{ACKNOWLEDGEMENTS}

Thanks to the MA Al-Amin Islamic Boarding school students who have contributed to this study. The author hopes that this study can increase understanding regarding the interconnection of science and the Qur'an and can increase our faith in the gifts of God.

\section{REFERENCES}

Acedo, L. (2017). Modified newtonian gravity as an alternative to the dark matter hypothesis. Galaxies, 5(4). https:// doi.org/10.3390/galaxies5040074

Cragun, R. T. (2015). Science and religion. In J. D. Wright (Ed.), International Encyclopedia of the Social \& Behavioral Sciences (2nd ed., pp. 172-175). Elsevier. https:/doi.org/10.1016/B978-0$\underline{08-097086-8.84049-0}$

Creswell, J. W., \& Clark, V. L. P. (2011). Designing and Conducting Mixed Methods Research (2nd ed.). Sage Publishing.

Erwin, E., Hayat, M., \& Sutarno, S. (2017). Epistemologi dan keterbatasan teori gravitasi. Titian Ilmu: Jurnal Ilmiah Multi Sciences, 9(1), 33-40. https:// doi.org/10.30599/jti.v9i1.79

Foster, B. (2011). Fisika Terpadu Untuk SMA/MA Kelas XI Semester 1. Erlangga.

Freedman, Y. a. (2002). Fisika Universitas. Erlangga.

Hamzah, M. (2016). Konsep gaya tarik menarik (gravitasi) dalam perspektif Al-Qur'an dan sains kajian surat Al-Hajj: 65. SPEKTRA: Jurnal Kajian Pendidikan Sains, 2(2), 100-132.

Hendi, S. H., Corda, C., Mazharimousavi, S. H., Momeni, D., Sepehri-Rad, M., \& Saridakis, E. N. (2017). Classical and quantum gravity and its applications. Advances in High Energy Physics, 2017. https://doi.org/10.1155/2017/9736761

Khoiri, A. (2018). Al-Qur'an dan fisika (Telaah konsep fundamental: Waktu, cahaya, atom, dan gravitasi). Prosiding Seminar Nasional Pendidikan Fisika FITK UNSIQ, 1(1), 92-102.

Mufid, F. (2014). Islamic sciences integration. Qudus International Journal of Islamic Studies, 145160. https:// doi.org/10.21043/qijis.v2i2.1565

Nurrohman. (2019). Ayat-ayat sains. Noktah.

Othman, M. Y. H. (2015). Appreciation of science in Al-Qur'an. Academic Journal of Interdiciplinary, 4(3), 89-96. https://doi.org/10.5901/ajis.2015.v4n3p89

Purwanto, A. (2015). Ayat-Ayat semesta Sisi al-Qur'an. Mizan.

Qurashi, M. (1989). Basic concepts of physics in the perspective of the Qur'an. Islamic Studies, 28(1), 55-75.

Rusydin. (2008). Gaya gravitasi dalam prespektif Al-Qur'an (Publication No. 1257) [Undergraduate honors thesis, Sunan Kalijaga State Islamic University]. Institutional Repository of Sunan Kalijaga State Islamic University. http:// digilib.uin-suka.ac.id/1257/

Shamey, R. (2015). Newton, (Sir) Isaac. In M. R. Luo (Ed.), Encyclopedia of Color Science and Technology. Springer. https:// doi.org/10.1007/978-1-4419-8071-7_364

Sunardi, Sabry, M. S., \& Arsyad, A. (2019). Isyarat adanya gravitasi bumi (suatu kajian tahlili terhadap QS. Al-Baqarah/2:74. Tafsere, 7(2), 125-144.

Suryabrata, S. (2004). Psikologi Pendidikan. Raja Grafindo.

Yusoff, M. Y. Z. M., \& Daneshgar, M. (2011). Islam and the relation of science and the Qur'an. International Conference on Humanities, Society and Culture IPEDR, 20, 53-57. 
Muslim Students' Understanding of The Interconnection of Gravity in Science and The Qur'an https://doi.org/10.46627/sipose.v1i3.54

Author (s):

* Kamila Amalia

Department of Physics, Faculty of Mathematics and Natural Science,

Universitas Negeri Surabaya,

Jl. Ketintang, Surabaya 60231, Indonesia

Email: kamila.17030184011@mhs.unesa.ac.id

Suliyanah

Department of Physics, Faculty of Mathematics and Natural Science,

Universitas Negeri Surabaya

Jl. Ketintang, Surabaya 60231, Indonesia

Email: Suliyanah@unesa.ac.id 